\title{
Designing Web Sites for Customer Loyalty Across Business Domains: A Multilevel Analysis
}

\author{
SUNIL MITHAS, NARAYAN RAMASUBBU, M.S. KRISHNAN, AND \\ CLAES FORNELL
}

SunIL Mithas is an Assistant Professor at the Robert H. Smith School of Business at the University of Maryland. He completed his Ph.D. at the Ross School of Business, University of Michigan. Prior to pursuing his Ph.D., he worked for ten years in various engineering, marketing, and general management positions with Tata Steel and Tata Ryerson in India. He is primarily interested in understanding how IT contributes to firm performance and how firms can better manage their IT resources. His research has appeared or is forthcoming in the Journal of Management Information Systems, Journal of Marketing, Production and Operations Management, Statistical Science, and Information Technology and Management. His research has been featured by leading business publications such as MIT Sloan Management Review, Bloomberg, Computerworld, InformationWeek, and Optimize. His papers have won the Best Doctoral Paper Award at CIST-INFORMS 2004 and Best Paper nomination at ICIS 2005. He won the Best Reviewer Award at CIST-INFORMS 2005.

NARAYAN RAMASUBBU is an Assistant Professor at Singapore Management University. He completed his Ph.D. in Business Administration at the Ross School of Business, University of Michigan. His research interests include software engineering economics, business value of IT, distributed product development, and software product standardization and customization. Prior to pursuing his Ph.D., he worked with SAP AG and CGI Inc. His research has appeared or is forthcoming in Journal of Management Information Systems, Decision Support Systems, and IEEE Software.

M.S. KRISHNAN is Mary and Mike Hallman e-Business Fellow and Professor of Business Information Technology at the Ross School of Business, University of Michigan. Dr. Krishnan is also a Codirector of the Center for Global Resource Leverage: India at the Ross School of Business. His research interests include corporate IT strategy, the business value of IT investments, management of distributed business processes, software engineering economics, and metrics and measures for quality, productivity, and customer satisfaction for software and other IT products. In January 2000, the American Society for Quality (ASQ) selected him as one of the 21 voices of quality for the twenty-first century. His research has appeared in several journals, including Management Science, Information Systems Research, Strategic Management Journal, Harvard Business Review, and Sloan Management Review. He currently serves on the editorial board of several academic journals, including Management Science and Information Systems Research.

Journal of Management Information Systems / Winter 2006-7, Vol. 23, No. 3, pp. 97-127. 
Claes Fornell is the Donald C. Cook Professor of Business at the Ross School of Business and the Director of the National Quality Research Center (NQRC) at the University of Michigan. He has also served on the faculty of Northwestern University and Duke University. Professor Fornell is one of the world's leading experts on Customer Satisfaction Measurement and Customer Asset Management. He is responsible for the American Customer Satisfaction Index (ACSI). He has also developed a system that makes it possible to for a firm to identify those specific aspects of quality that have the largest effect on customer satisfaction and economic returns. Professor Fornell is the founder and chairman of CFI Group (www.cfigroup.com), a firm that develops and implements this system for individual firms. He is also Chairman of the Board of ForeSee Results, Inc. (www.foreseeresults.com), a company that uses ACSI technology to capture the voice of online customers with respect to Web sites. Professor Fornell has written more than 80 published articles and several books. He has served on the editorial board of all the major academic journals in marketing. He frequently appears on radio, television, and in the press as a commentator on business and economics.

ABSTRACT: Web sites are important components of Internet strategy for organizations. This paper develops a theoretical model for understanding the effect of Web site design elements on customer loyalty to a Web site. We show the relevance of the business domain of a Web site to gain a contextual understanding of relative importance of Web site design elements. We use a hierarchical linear modeling approach to model multilevel and cross-level interactions that have not been explicitly considered in previous research. By analyzing data on more than 12,000 online customer surveys for 43 Web sites in several business domains, we find that the relative importance of different Web site features (e.g., content, functionality) in affecting customer loyalty to a Web site varies depending on the Web site's domain. For example, we find that the relationship between Web site content and customer loyalty is stronger for information-oriented Web sites than for transaction-oriented Web sites. However, the relationship between functionality and customer loyalty is stronger for transaction-oriented Web sites than for information-oriented Web sites. We also find that government Web sites enjoy greater word-of-mouth effect than commercial Web sites. Finally, transaction-oriented Web sites tend to score higher on mean customer loyalty than do information-oriented Web sites.

KEY WORDS AND PHRASES: business value of information technology, customer loyalty, customer relationships, customer satisfaction, e-commerce, hierarchical linear modeling (HLM), Web site content, word-of-mouth.

FIRMS SPEND MILLIONS OF DOLLARS TO ATTRACT new customers and to retain their existing customers. Previous research suggests that customer loyalty and customer retention are important predictors of market value and stock price [25]. Information technology (IT) plays a central role in supply-chain, order fulfillment, and customer relationship processes to improve customer loyalty [7, 39, 46, 48, 55]. Among customer-related IT investments, the creation and maintenance of an effective Web site are critical elements of IT and of the marketing strategy of firms [22, 61]. Research 
shows that consumers are more likely to visit, purchase, and repurchase from betterdesigned online stores [40]. Given the critical role of a firm's Web site in its marketing and communication strategy, it is important for business and marketing managers to understand the characteristics of Web sites that influence consumer behavior and customer loyalty.

Despite significant investments in the creation and maintenance of Web sites, there is limited academic research on the relative importance of individual elements of Web site design and their effect on customer loyalty. Thus far, much of the research has focused on the development of reliable and valid metrics to evaluate the effectiveness of Web site design. Many of these studies use laboratory and field experiments to simulate consumer behavior (for a review, refer to [63]). Although these studies have enhanced the understanding of Web site effectiveness metrics, few have used actual online consumers as respondents to collect data, making it difficult to generalize the findings to the real-world online population $[1,39,40]$. In addition, with some notable exceptions [41], few studies have systematically investigated the relationship between individual Web site design elements and customer loyalty across business domains. Studies by Agarwal and Venkatesh [1] and Liang et al. [41] provide preliminary evidence and emphasize the need to consider business domain and industry effects systematically to model the effect of Web site elements on customer loyalty.

In this paper, we examine the effect of Web site design elements (e.g., content, functionality, and structure) on customer loyalty to Web sites. We also model the variation in the relationship between Web site characteristics and customer loyalty considering the business domain in which Web sites are embedded. We use a large data set of more than 12,000 actual online customers of $43 \mathrm{Web}$ sites in several business domains to test our conceptual model and hypotheses. Given the multilevel nature of our research questions and the nested structure of the data, this study uses multilevel analysis (i.e., hierarchical linear modeling [HLM]) to study the determinants of Web site loyalty.

This study makes four main contributions. First, we study how the relationship between Web site elements and customer loyalty varies as a function of the business domain or industry attributes. This contribution is consistent with a recent call for research to take the "industry seriously" in information systems (IS) research [16].

Second, this research illustrates the use of HLM, a relatively new technique in the IS domain, to study multilevel and cross-level relationships, providing a richer understanding of the determinants of customer loyalty to Web sites. The use of HLM in this study enables us to demonstrate how researchers can explicitly account for the nested nature of their data and investigate multilevel research questions. Through this contribution, we hope that this research will both engender more studies with careful attention to the multilevel nature of research questions and highlight the potential applicability of HLM in this domain, particularly for studies that specifically investigate industry effects.

Third, we provide rigorous, confirmatory evidence for the effect of several Web site design features on customer loyalty to Web sites. By analyzing a large data set of 
actual online consumers, we estimate the relative importance of various design elements and their effect on customer loyalty to a Web site. Our work builds on previous exploratory work that uses experiments or field studies with a limited sample size to develop reliable metrics and scales. From a managerial perspective, an understanding of the relative importance of Web site design factors will help managers better allocate scarce resources.

Fourth, this study further extends the business value of IT literature $[8,14,36]$ by studying the value of a specific type of IT application (i.e., Web sites) in terms of customer loyalty, an intangible but increasingly important measure in a customerbased economy. This contribution is in line with recent research that focuses on the revenue and customer satisfaction side of IT's effect rather than productivity or cost $[45,47,48,59]$. Brynjolfsson notes, "Going forward, there will be a renewed emphasis on what the [chief information officer] can do to bring in new revenue, increase customer satisfaction, and enhance focus on benefits side, not just the cost side" [17, p. 78].

\section{Theory}

\section{Background Literature}

CUSTOMER LOYALTY IS AN IMPORTANT DETERMINANT of long-term business success. Several studies have documented a favorable effect of customer loyalty on usage levels, future revenues, cost of future transactions, price elasticity, customer defection, warranty, and field service costs $[2,10]$. Among the studies that relate customer loyalty to overall firm performance, Anderson et al. [3] find a strong relationship between customer loyalty and Tobin's $Q$ (as a measure of shareholder value) after they control for fixed, random, and unobservable factors. Fornell et al. [25] show that firms with higher customer loyalty provide higher stock returns with less risk.

IT is an important enabler of customer loyalty. Previous research shows that IT investments have a positive effect on consumer surplus at the economy level, and researchers have argued that firms can also benefit from IT investments in terms of customer satisfaction [12, 13, 14, 29]. Indeed, recent work shows that IT investments affect customer satisfaction through their effect on perceived value and perceived quality [47]. Research also shows that customer-related IT systems, such as customer relationship management systems, affect customer satisfaction because they enable improvement in customer knowledge and related processes [34, 48, 62]. However, few studies have measured Web site effectiveness in terms of customer loyalty, and few have studied the effect of Web site elements on customer loyalty.

Measuring effectiveness of Web sites in terms of customer loyalty is important for three reasons. First, managers need to know the effectiveness of their Web site in meeting the needs of their Web site visitors to improve loyalty to their Web site. This is particularly important because the online environment makes it possible for customers to switch to competitors with just one click [51]. Second, managers need a 
reliable tool and metric to track the effectiveness of Web site improvement proposals. Industry reports suggest that Fortune 100 companies spend an average of \$1.5 to \$2.1 million per year on Web site modifications without knowing whether such modifications actually make the Web site easier to use [35]. Given that substantial changes in such Web site features as content, functionality, and structure are expensive, it becomes important to measure reliably the effectiveness and relative importance of such changes in terms of customer loyalty. Third, an understanding of Web site visitor profiles and their needs enables a company to tailor not only its prospective customer interface but also its future line of product features and offerings.

As noted earlier, recent research in the IS literature has proposed and validated several new metrics for the evaluation of Web site effectiveness. Several of these metrics are related to content, functionality, and structural features. Some studies also explore the effect of usability features on measures of Web site success [43, 49]. These studies have used exploratory methods to validate their proposed metrics. However, few studies use data from actual online customers across Web sites to test hypotheses about the relationship between Web site design elements and Web site success. More important, few studies systematically model the clustering of customers within Web sites and account for methodological issues that arise as a result of dependence of observations within a Web site [53]. Furthermore, previous research has not specifically studied the relative importance of specific design parameters, such as content, functionality, and structure, in influencing customer loyalty. Studying the relative importance of Web site design features is important to inform managerial decision making on prioritizing improvements in redesign efforts. For example, if research suggests that customers value Web site content more than functionality, managers are better off making improvements in content.

To derive empirical generalizations about the effect of Web site elements on Web site loyalty, it is also necessary to study the moderating effect of the business domain in such relationships [16]. Researchers have called for studies to examine the moderating effect of an industry or business domain in understanding the effect of Web site design features on customer loyalty. For example, Liang et al. observe, "Different relationships may exist in other industries and business models. Therefore, one must be careful when the result is generalized and applied to other industries" [41, p. 544]. Likewise, Agarwal and Venkatesh note that "there may be an overall industry effect related to the quality of the website" [1, p. 180]. Our efforts are consistent with recent research that considers such industry effects to explain salaries of IT professionals [5], market value of firms [28], and firm performance [41].

\section{Theoretical Model and Hypotheses}

Our analysis of previous research reveals that several Web site design features are considered important determinants of customer loyalty. Of these, we focus on the three that have been mentioned in several studies as determining customer loyaltycontent [1, 41, 49], functionality [41, 49], and structure [1, 65]. Although researchers have studied other dimensions of Web site design as well, we prefer a parsimonious 
model of customer loyalty to Web sites that uses these three predominant design elements. Furthermore, although our model builds on previous work, we are able to illustrate the use of a relatively new technique while keeping the exposition simple.

We develop a generic scheme to classify Web sites, and we conceptualize the business domains of Web sites along three dimensions-domain (informational or transactional), ownership (government or commercial), and product offering (goods or services). We believe that the relatively generic nature of this framework allows for potentially greater comparability to future research findings from studies that employ this framework in specific industries.

Our conceptualization of business domain encompasses and extends the notion of Web sites being embedded in particular industries. For example, Kim et al. [37] conceptualize Web site domain in terms of distinct businesses, such as virtual malls, stock brokerages, search portals, and online games. They consider Web sites that belong to these business domains distinct from one another and conduct separate analysis in each domain. Agarwal and Venkatesh [1] and Liang et al. [41] also anticipate the importance of the effects of the business domain by pointing to the salience of industry effects in their study.

We hypothesize that the effect of Web site elements on customer loyalty will be moderated by the business domain of the Web site because customer expectations and online behavior differ significantly across business domains. Analysis of customers' online behavior using traffic logs reinforces this view [19]. For example, customer loyalty may be more sensitive to a Web site's functionality for transaction-intensive Web sites (e.g., online storefronts) than for information-intensive Web sites (e.g., government departments, newspapers). Information-intensive Web sites may be relatively sticky because of their specialized niche or unique content offering. For such Web sites, customers may be more tolerant even if other functionality is relatively inferior. In other words, because content primarily draws customers repeatedly to information-oriented Web sites, functionality of the Web site may have less of a role in influencing customer loyalty than would be the case for transaction-oriented Web sites.

Figure 1 shows our research model. In this figure, individual Web site characteristics—-such as content, functionality, and structure (i.e., Level 1 variables)—and outcome variables (customer loyalty) are measured at the customer level and appear in ovals. The Web site-level variables appear in the rectangles. The arrows for H1a through $\mathrm{H} 1 \mathrm{c}$ represent our first research question: How do customer evaluations of individual Web site characteristics affect customer loyalty? The arrows for $\mathrm{H} 2$ through H4 represent our second research question: How does the effect of customer-evaluated Web site characteristics on customer loyalty vary across business domains? Next, we discuss the theory underlying our conceptual framework. ${ }^{1}$

Web Site Characteristics and Customer Loyalty

Relating Web Site Content to Customer Loyalty. Web sites differ in their ability to offer content of superior quality, depending on the extent to which they can provide 


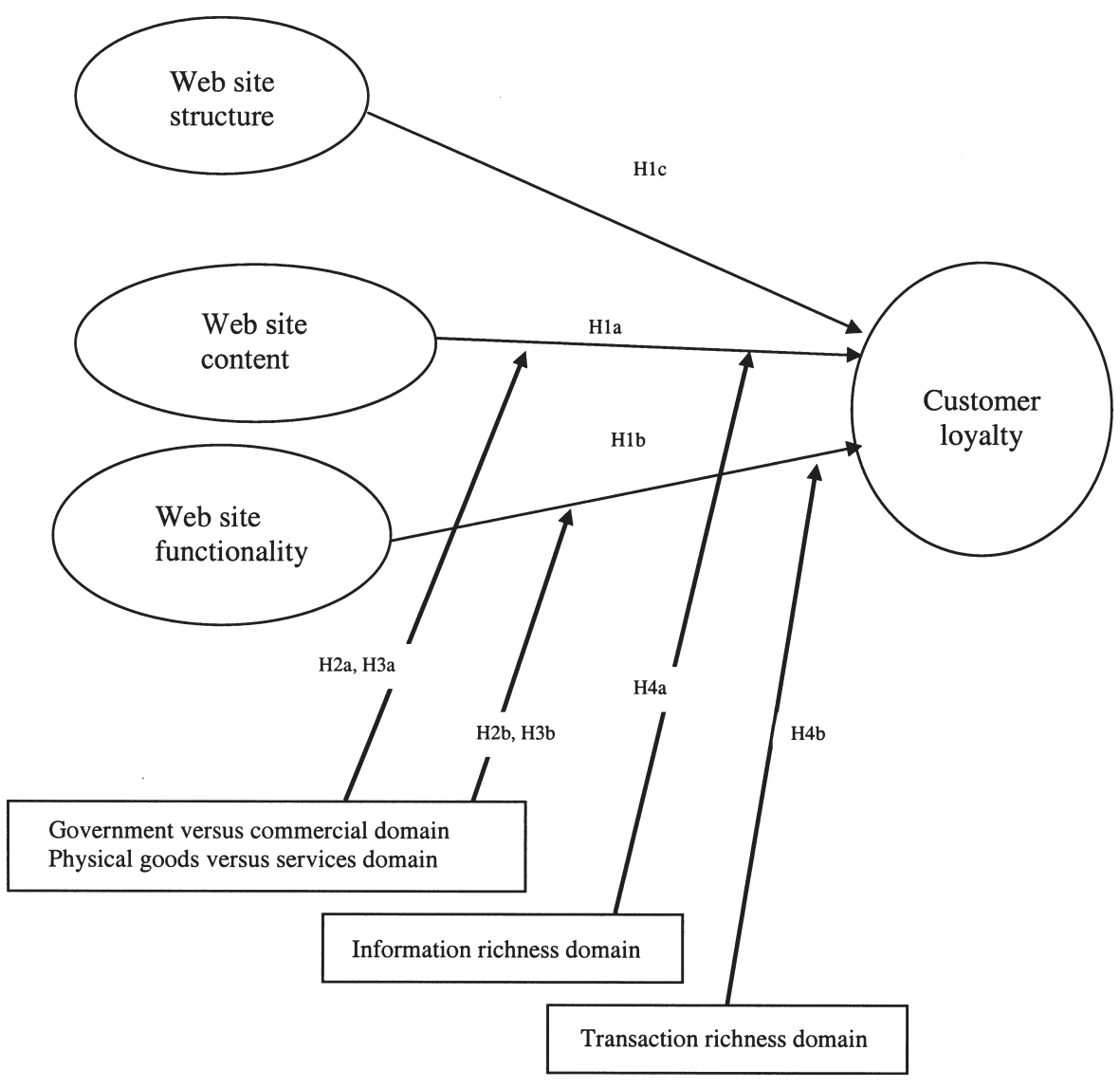

Figure 1. Conceptual Model

accurate and updated information of high quality to consumers. Content pertains not only to the verbal information but also to the usage of graphics, animated objects, pictorial representations, and other multimedia artifacts present in the Web site. The ability of the Web site to offer superior content depends on infrastructure capabilities and is a design parameter that is in the control of managers. For example, managers can control the degree of freshness of Web site content by making design choices, such as use of dynamic pages and the more frequent updating of content, depending on business needs and customer expectations.

The content of a Web site is a key parameter that influences users' attitudes toward the Web site. Daft and Lengel [18] suggest that the quality and accuracy of information in an exchange have a significant effect on user understanding and perceived effectiveness of communication. Accuracy of content makes a Web site more credible. Users are likely to value the quality of information more highly than the quantity of information. Outdated and irrelevant information is likely to mislead and confuse users. Web sites with constantly updated, fresh, and relevant content are more likely to attract and retain users. Previous research on scale development for Web site content and its no- 
mological validity has reported a positive and significant relationship between content and success [1, 49]. Agarwal and Venkatesh [1] report that Web site content was the most important attribute that consumers preferred in their study. Thus,

Hla: Higher scores on perceived quality of Web site content are positively associated with higher customer loyalty.

Relating Web Site Functionality to Customer Loyalty. The functionality of a Web site refers to perceived service attributes, such as perceived usefulness and convenience of the offering. Technology diffusion literature suggests that user satisfaction with an adopted service is positively associated with perceived usefulness, perceived ease of use, and the degree to which the offering meets the user's needs [58]. The technology acceptance model, which draws on technology diffusion literature in the context of IS, posits that perceived ease of use and perceived usefulness positively influence the user's behavior toward the system [20]. Koufaris [38] applies the technology acceptance model to predict consumer loyalty by treating Web sites as a technology system and the Web user as a computer user. In addition, Kim et al. [37] report that providing convenient functions for customers to complete their intended activities is important to ensure superior customer satisfaction in Internet-enabled companies. Users are more likely to accomplish their objectives when the Web site has greater functionality. On the basis of the foregoing discussion, we posit that a higher perceived functionality of a Web site is positively associated with the customer loyalty to the Web site.

H1b: Higher scores on perceived Web site functionality are positively associated with higher customer loyalty.

Relating Web Site Structure to Customer Loyalty. The structure of a Web site refers to its overall organization and layout. These features influence the consumer experience and customer loyalty. An intuitive layout of a Web site that has clear organization is likely to lead to higher levels of user success in terms of being able to reach the desired content or functionality of a Web site. Long before the widespread adoption of the Internet, Daft and Lengel [18] argued from a media richness perspective that structural characteristics of information exchange media play a key role in the effective utilization of information. In the case of Web sites, these structural characteristics pertain to the organization of information within and across individual Web pages; sequential organization of individual Web pages using hyperlinks; navigation across different sections of the Web site; and other aesthetic features, such as layout style. Previous research suggests the need for considering navigational ease an important factor in Web site design. For example, Palmer [49] notes that Web site users associate design, layout, and sequencing arrangement with greater perceived success. Thus,

H1c: Higher scores on perceived Web site structure are positively associated with higher customer loyalty. 
The Role of Web Site Domain in the Relationship Between Web Site Characteristics and Customer Loyalty

As we noted previously, domain or industry effects are likely to be important in gaining a contextual understanding of the effect of Web site design features on customer loyalty. Kim et al. [37] suggest the metaphor of "buildings" for Internet companies and propose metrics based on structural, functional, and representational considerations. Typically, buildings within a locality share many common characteristics and are different from buildings in other localities. The notion of nesting or embeddedness of a focal unit within a wider entity has spawned a rich stream of research in other social sciences, such as education (e.g., school effects research) and sociology (e.g., neighborhood effects research).

Extending the metaphor of buildings to Web sites, we propose that Web sites that belong to distinct business domains may vary significantly, depending on the business goals and operational characteristics of the domain. For example, government Web sites might be designed for public information dissemination as their prime motive, whereas commercial Web sites might focus on achieving marketing and sales objectives. Empirical studies have also reported differences in customer expectations across Web sites. For example, in a survey of user perceptions on Web site quality, Zhang and von Dran [64] report that users' expectations across Web sites in educational, financial, governmental, entertainment, and health services domains are significantly different. Whereas content ranks high in financial and health services contexts, structure (or navigation) is more important in educational and governmental contexts. It is important to consider such potential variance in the relationship between Web site design elements and customer behavior across business domains.

As we noted previously, we classify Web sites into business domains on the basis of ownership (i.e., we distinguish between government and commercial Web sites), Web site offering (i.e., those that sell goods versus services), and the degree to which Web sites deliver information or support commercial transactions (information- versus transaction-oriented sites) from a customer viewpoint. Our focus on relatively smaller but more salient dimensions of Web sites is consistent with previous research. For example, Liang et al. [41] classify Web sites into two categories, information-oriented and transaction-oriented Web sites, to examine the effect of electronic commerce models and industrial characteristics on firm performance. Although initial work along these lines proposed several ways of classifying Web sites [31], following more recent work [30, 41], we assign all Web sites to information and transaction domains. On the basis of previous research [4, 15], we also consider two other business domains for categorizing Web sites - their ownership (government or nongovernment) and the nature of their offering (goods versus services).

Government Versus Commercial Web Sites. Differences between public- and privatesector organizations have received significant attention [57]. The distinguishing ownership structures between government and commercial organizations may lead to a distinct set of objectives. Whereas commercial firms focus on maximization of profits 
for private owners, government organizations respond to the society as a whole and tend to maximize social utility. Ring and Perry [57] suggest that factors such as policy ambiguity, transparency requirements, customer diversity, and time constraints contribute to decision-making differences between government and commercial organizations. Extending this idea further, we posit that the nature of government and private ownership can also affect information management and communication policies.

It is important to analyze the effect of Web site characteristics on customer loyalty by considering the nesting of Web sites within the public or private domain. This is because Web site ownership may influence design and customer expectations. Hoos [33] argues that assumptions involved in the design of commercial IS may not hold in the public domain and subsequently calls for specifically crafted systems for government organizations. Caudle et al. [15] show that the public sector has multiple, conflicting, and intangible goals that make managing IS in the public sector different from the commercial sector. Specifically, they argue that public IS should enable the handling of lower allocation efficiencies, several legal and formal constraints, a wider concern for issues of public interest, more complex decision-making criteria, and an easy transfer of technology. Drawing on these research findings, we posit that Web site design characteristics (along with other IS components) and their effect on customer loyalty may vary significantly between government and commercial Web sites.

H2a: The effect of Web site content on customer loyalty is higher for commercial Web sites than for government Web sites.

$H 2 b$ : The effect of Web site functionality on customer loyalty is higher for commercial Web sites than for government Web sites.

Goods Versus Services Web Sites. Manufacturing and service firms differ on several parameters because of the nature of output and the underlying production process [44]. In addition, the nature of customer interactions and experiences also varies significantly across the manufacturing and service sectors. Previous research [48, 50] has suggested that the customer view of "quality" differs across products and services. On the basis of similar reasoning, researchers have argued that the drivers of customer equity may be different across industry sectors [60]. We expect that the nature of products and services that Web sites offer affects customer expectations and experiences with Web sites. Prior research on customer satisfaction has consistently found significant differences between goods and services industries [26, 48].

IT applications, such as Web sites, can play a greater role in enabling service-sector companies to improve their customer loyalty because the service business is more information intensive. Barua and Mukhopadhyay [8] note that the services sector may stand to gain more than the manufacturing sector from IT applications because services require adaptation to individual customer requirements, which can be accomplished by leveraging IT capabilities to customize product delivery and consumption experience in real time. For example, the innovative use of IT has enabled firms such as Amazon.com (retailing services) and Charles Schwab (financial services) to record high levels of customer loyalty. Marketing researchers have also argued that 
IT may have greater leverage for achieving customer loyalty in service firms that are more information intensive [4]. Extending sectoral differences between goods and services observed in previous research to Web site offerings, we posit that the nature of the industry (manufacturing or services) may moderate the effect of Web site characteristics on customer loyalty. In particular, Web sites that offer services are likely to have a stronger relationship between design characteristics (content and functionality) and customer loyalty.

H3a: The effect of Web site content on customer loyalty is higher for Web sites that offer services than for Web sites that offer goods.

H3b: The effect of Web site functionality on customer loyalty is higher for Web sites that offer services than for Web sites that offer goods.

Information-Versus Transaction-Oriented Web Sites. Web sites can be broadly classified into the information or the transaction domain, depending on customer perceptions of the relative superiority of their content and functionality [41]. However, in practice, most Web sites are likely to have different degrees of information or transaction richness. Because customers of information-oriented Web sites are likely to value content more than functionality, we expect that content will have a greater effect on customer loyalty for information-oriented Web sites than for transactionoriented Web sites. Likewise, because customers of transaction-oriented Web sites are likely to place greater value on convenience or functionality than on content, we expect that Web site functionality improvements will have a greater effect on customer loyalty for transaction-oriented Web sites than for information-oriented Web sites.

H4a: Web site content has a greater effect on customer loyalty for informationoriented Web sites than for transaction-oriented Web sites.

H4b: Web site functionality has a greater effect on customer loyalty for transaction-oriented Web sites than for information-oriented Web sites.

\section{Method}

\section{Research Setting and Data}

WE COLLECTED ARCHIVAL DATA FOR THIS STUDY from a leading firm that specializes in tracking customer loyalty of Web sites through Web-based questionnaires. This firm designs and operationalizes online customer satisfaction surveys for its clients and uses an application service provider model to deliver its services. The online survey captures the voice of the customers in real time, while they experience and use the client's Web site. A small piece of JavaScript inserted into the client's Web site HTML triggers a brief survey to pop up while customers are using the client's Web site and requests their participation in the feedback program. 
Customers responded to the satisfaction survey by answering a small set of questions when they were visiting the Web sites. Customers rated their perceived satisfaction with individual Web site characteristics—such as content, functionality, and structure-and the extent to which they will recommend the Web site to others (assessed on a scale from 1 to 10). Our research site uses an academically rigorous methodology for assessing customer loyalty [26]. Although this firm had more than 50 clients at the time we collected our data, we were able to obtain complete data for only 43 Web sites, along with their domain classification.

These Web site surveys were conducted between March 2003 and July 2003. Because the survey was short, the only incentive provided to participants was to be entered into a prize drawing. The survey instrument we used in this study was designed on the basis of a literature analysis and was adapted from other validated instruments, such as the American Customer Satisfaction Index, used in previous research studies [25, 26, 45]. Compared with mail questionnaires, Web questionnaires must be relatively short to obtain a high response rate because consumers have a short attention span when they are surfing Web sites. Even in mail surveys, questionnaire length may be a serious concern because of its potentially adverse effect on the quality of survey data due to respondent fatigue, low survey response, and item nonresponse. To increase the response rate without compromising the quality of the data collection effort, our research site uses split-survey administration. In this approach, if a particular construct consists of a three-item scale, each respondent is randomly administered only two of the three items of this multiple-item construct. Use of the randomization

procedure across customers ensures both a high response rate and coverage of all the constructs across respondents. Because the data for only one item per block (i.e., construct) is missing by design and is missing at random, use of such data leads to unbiased parameter estimation [42].

\section{Constructs and Measures}

\section{Referral Likelihood (RECO)}

To estimate the effect of these Web site characteristics on customer loyalty, we use referral likelihood (i.e., the likelihood that a customer will recommend a Web site to others) as a measure of customer loyalty. Referral likelihood measures a Web site customer's word-of-mouth behavior. Our focus on customer word-of-mouth behavior as a measure of customer loyalty is in line with recent research that suggests that this is a reliable and effective metric for measuring customer loyalty $[11,21,56]$ that has implications for firm performance. Although previous research in the IS literature has linked design elements to customer satisfaction and intentions to return to a Web site [22, 43, 49], there is limited work that has operationalized Web site effectiveness in terms of customer word-of-mouth behavior. Thus, we use referral likelihood as our primary dependent variable in this study to focus on word-of-mouth behavior in the online context. We believe that our research complements previous work by providing an alternative way of measuring customer loyalty. 
In line with previous research, we measure referral likelihood with a single item that asks respondents to indicate the likelihood (assessed on a scale ranging from 1 to 10) that they will recommend the Web site to someone else [56]. Use of single-item measures as a dependent variable is common when the item is unambiguous and is consistent with previous research [23].

\section{Content (CONT)}

We measure the content of a Web site with three items-accuracy of information, quality of information, and freshness of content. The items are similar to those used in previous research by Agarwal and Venkatesh [1], Davern et al. [19], and Palmer [49].

\section{Functionality $(F U N C)$}

We measure the functionality of a Web site with three items-usefulness of services provided, convenience of services, and the extent to which the Web site enables customers to accomplish their goals. The items are similar to those used in previous research by Balasubramanian et al. [6], Palmer [49], and Zhang et al. [65].

\section{Structure $(S T R U)$}

We measure structure with three items — readability, clarity, and layout. The items are similar to those used in previous research by Agarwal and Venkatesh [1] and Zhang et al. [65].

\section{Type of Web Site (INFORMATION and TRANSACTION)}

One way to classify Web sites in terms of their information and transaction richness is by averaging customer responses on content and functionality scores. The use of such derived variables provides a control for higher-level factors in a study and may be best explained with the help of an example from education research [53]. Consider the effect of parents' income on a child's learning. Whereas parents' income is likely to have an effect on a child's learning, the average income of parents residing in the same neighborhood may have an independent effect on a child's learning. Extending this logic to Web site context, the average content of a Web site may have an effect on an individual customer's loyalty beyond the effect of the customer's own evaluation of content quality because a Web site that scores higher on average content may be relatively superior in content to another site with a lower average content rating. At the individual customer level and for a specific Web site, content quality has a more contextual meaning that depends on customer characteristics and the specific purpose the customer had in mind at the time of Web surfing; however, at the Web site level, average content quality provides a proxy measure of Web site superiority on content compared with other Web sites. The variable INFORMATION describes the extent to which Web sites are better at providing content to their customers (higher 
scores on INFORMATION indicate better content), and the variable TRANSACTION describes the extent to which Web sites are better at providing functionality to their customers.

\section{Nature of Web Site Offering (PHYGOOD)}

Consistent with previous research $[26,48]$, we measure the nature of a Web site with an indicator variable: $1=$ goods, and $0=$ services.

\section{Web Site Ownership (GOVT)}

We also measure Web site ownership with an indicator variable: 1 = government Web sites, $0=$ commercial Web sites. Our sample does not contain Web sites that belong to nonprofit organizations.

Table 1 summarizes the variables we used in this study and their correspondence with the constructs and items used in previous studies. We obtained the data collected from 12,418 individual customers for $43 \mathrm{Web}$ sites from our research site. We also obtained information about the Web site-level variables from our research site. Of the 43 Web sites, 10 offer physical goods, and 33 offer services. In terms of ownership, 27 Web sites belonged to commercial enterprises, and 16 were government organizations. We characterized the degree to which a Web site can be classified as an INFORMATION or a TRANSACTION Web site on the basis of its mean score on content and functionality by averaging the customers' scores for these attributes for a given Web site. This average score on content and functionality provides a proxy measure of the relative ranking of Web sites on information and transaction intensity based on customer input. Note that this coding scheme of classifying Web sites on information and transaction intensity uses customer perception as an input and thus avoids reliance on researcher coding. It is also consistent with the practice of coding contextual variables in the HLM literature [53]. We used the average of items belonging to a scale to operationalize our theoretical constructs. The selection of survey items based on prior academic research helped ensure the content validity of the items used in this research. Because of the use of formative scales, conventional methods of assessing reliability and discriminant validity that are appropriate for reflective scales do not apply to this study [1].

Table 2 shows the descriptive statistics for the variables. Although the mean scores on customer ratings are high, these are consistent with previous research that has also documented the skewness of customer ratings [24], and such skewness does not bias our parameter estimates [27]. We also calculated the correlations among variables, and even though some of the correlations between independent variables fall on the higher side, multicollinearity is not a serious concern in our data set for three reasons. First, the large sample size we used in this study ensures that variables have enough independent variation to allow estimation of structural relationships. Second, multicollinearity tends to inflate standard errors of corresponding variables, and therefore estimates in the presence of multicollinearity are likely to be on the conservative side 
Table 1. Constructs and Questionnaire Items

\begin{tabular}{|c|c|c|}
\hline Construct & Questionnaire items & Reference \\
\hline \multicolumn{3}{|c|}{ Within Web site variables (Level 1 variables) } \\
\hline $\begin{array}{l}\text { Content } \\
(C O N T)\end{array}$ & $\begin{array}{l}\text { Please rate the accuracy of information on } \\
\text { this site. } \\
\text { Please rate the quality of information on this site. } \\
\text { Please rate the freshness of content on this site. }\end{array}$ & {$[1,19,40,49]$} \\
\hline $\begin{array}{l}\text { Functionality } \\
(F U N C)\end{array}$ & $\begin{array}{l}\text { Please rate the usefulness of the services } \\
\text { provided on this site. } \\
\text { Please rate the convenience of the services on } \\
\text { this site. } \\
\text { Please rate the ability to accomplish what you } \\
\text { wanted to on this site. }\end{array}$ & {$[6,40,49,65]$} \\
\hline $\begin{array}{l}\text { Structure } \\
(S T R U)\end{array}$ & $\begin{array}{l}\text { Please rate the ease of reading this site. } \\
\text { Please rate the clarity of site organization. } \\
\text { Please rate the clean layout of this site. }\end{array}$ & {$[1,65]$} \\
\hline $\begin{array}{l}\text { Referral } \\
\text { likelihood } \\
(R E C O)\end{array}$ & $\begin{array}{l}\text { Likelihood to recommend this site to someone } \\
\text { else. }\end{array}$ & {$[6,26]$} \\
\hline \multicolumn{3}{|c|}{ Across Web site variables (Level 2 variables) } \\
\hline $\begin{array}{l}\text { Web site } \\
\text { offering } \\
(\text { PHYGOOD) }\end{array}$ & Goods versus service $($ goods $=1$, services $=0$ ) & [4] \\
\hline $\begin{array}{l}\text { Web site } \\
\text { ownership } \\
\text { (GOVT) }\end{array}$ & $\begin{array}{l}\text { Government versus nongovernment } \\
\quad(\text { government }=1, \text { commercial }=0)\end{array}$ & {$[15,33]$} \\
\hline INFORMATION & $\begin{array}{l}\text { This variable represents average content of a } \\
\text { Web site. }\end{array}$ & {$[40,41]$} \\
\hline TRANSACTION & $\begin{array}{l}\text { This variable represents average functionality of } \\
\text { a Web site. }\end{array}$ & {$[40,41]$} \\
\hline
\end{tabular}

[27]. Third, because the use of centering reduces the effect of multicollinearity on parameter estimates, we centered our continuous variables in our HLM estimation, as we describe subsequently.

\section{Multilevel Analysis}

Our research questions are multilevel. First, we examine the effect of individual customer ratings for Web site characteristics (content, functionality, structure) on the customer's loyalty ratings for that Web site. Second, we investigate how the relationship between customer ratings of various Web site elements and Web site loyalty varies across sites by considering ownership (government or commercial), offering 
Table 2. Summary Statistics of Variables

\begin{tabular}{lcccc} 
Variable & Mean & $\begin{array}{c}\text { Standard } \\
\text { deviation }\end{array}$ & Minimum & Maximum \\
\hline Within Web site variables (Level 1) & $(N=12,418)$ & & \\
\hline CONT & 7.98 & 2.29 & 1 & 10 \\
FUNC & 7.86 & 2.50 & 1 & 10 \\
STRU & 8.10 & 2.24 & 1 & 10 \\
RECO & 7.94 & 2.76 & 1 & 10 \\
Across Web site variables (Level 2) $(N=43)$ & & \\
\hline PHYGOOD & 0.23 & 0.43 & 0 & 1 \\
GOVT & 0.37 & 0.49 & 0 & 9.01 \\
INFORMATION & 7.79 & 0.82 & 5.14 & 9.22 \\
TRANSACTION & 7.59 & 0.98 & 4.49 & \\
\hline
\end{tabular}

(physical goods versus digital goods), and the degree to which the Web site offers content or transaction support. The analytical strategy we followed herein is similar to that in educational research, in which exploration of school effects is carried out at multiple levels—-such as the child level, the class level, and the school district levelwith HLM [53]. For a more detailed and technical description of this methodology, refer to Raudenbush and Bryk [52] and Hoffmann [32].

Analysis of multilevel data poses three types of estimation difficulties-aggregation bias, misestimated errors, and heterogeneity of regression. Aggregation bias occurs when a variable takes different meanings at different levels of analysis. As we noted previously, our conceptualization of information and transaction Web sites and our use of the INFORMATION and TRANSACTION variables by aggregating customer responses on content and functionality provide an example of the estimation problem involved here. HLM addresses the potential confounding of variable interpretation by decomposing the effects of variables at separate levels of analysis. Misestimated standard errors may arise as a result of failure to account for the dependence of observations within a Web site. Hierarchical modeling avoids this problem by incorporating a unique random effect for each Web site. Heterogeneity of regression occurs when relationships between customer-evaluated characteristics and customer loyalty vary across Web sites. HLM permits the modeling of variation in intercepts and slopes across Web sites on the basis of Web site-level (Level 2) variables.

Our HLM analysis proceeded incrementally in three steps. In Step 1, we partitioned the total variance in customer loyalty into within-Web site variance (i.e., customerlevel variance within a Web site) and between-Web site variance (i.e., the variance between Web sites) through a fully unconditional model, which specifies no predic- 
tors at customer (Level 1) or Web site (Level 2) levels. Partitioning the variance of an outcome variable into between-Web site $\left(\sigma^{2}\right)$ and within-Web site $(\tau)$ components enables us to compute intraclass correlation ( $\mathrm{ICC}=\sigma^{2} /\left[\sigma^{2}+\tau\right]$ ) for that outcome variable. The ICC is used to quantify the total variability in an outcome that lies systematically between the groups (in our case, across Web sites). A very low ICC value suggests that there are no significant differences across units, whereas moderate or high ICC values (e.g., more than 10 percent) may indicate unit-level heterogeneity that can be modeled further using Level 2 predictors.

In Step 2 of the HLM analysis, we fit a random coefficients regression model by allowing predictors at the customer level (Level 1 or within-Web site) only. The random coefficients regression model provides within-Web site (Level 1) coefficients that can subsequently be modeled with Web site-level (Level 2) variables. By comparing the estimation of variance components from our fully unconditional model and from our random coefficients model, we determine the proportion of the total variance explained by within-Web site predictors.

In Step 3 of the HLM analysis, we model the randomly varying intercepts and slope coefficients (obtained in Step 2) through Web site, or Level 2, predictors, such as the average content and functionality, the nature of the offering, and ownership.

We estimated the following equations at customer and Web site levels. The withinWeb site (Level 1) model is as follows:

$$
Y_{i j}=\beta_{0 j}+\beta_{1 j} \times C O N T_{i j}+\beta_{2 j} \times F U N C_{i j}+\beta_{3 j} \times S T R U_{i j}+r_{i j},
$$

where $Y$ represents the customer referral as an outcome variable, subscript $i$ indexes customers, and subscript $j$ indexes Web sites.

The between-Web site (Level 2) models are as follows:

$$
\begin{aligned}
& \beta_{0 j}=\gamma_{00}+\gamma_{01} \times \text { PHYGOOD }_{j}+\gamma_{02} \times \text { GOVT }_{j}+\gamma_{03} \\
& \times \text { INFORMATION }_{j}+\gamma_{04} \times \text { TRANSACTION }_{j}+u_{0 j} \\
& \beta_{1 j}=\gamma_{10}+\gamma_{11} \times \text { PHYGOOD }_{j}+\gamma_{12} \times \text { GOVT }_{j}+\gamma_{13} \\
& \times \text { INFORMATION }_{j}+\gamma_{14} \times \text { TRANSACTION }_{j}+u_{1 j} \\
& \beta_{2 j}=\gamma_{20}+\gamma_{21} \times \text { PHYGOOD }_{j}+\gamma_{22} \times \text { GOVT }_{j}+\gamma_{23} \\
& \times \text { INFORMATION }_{j}+\gamma_{24} \times \text { TRANSACTION }_{j}+u_{2 j}
\end{aligned}
$$

and

$$
\beta_{3 j}=\gamma_{30}
$$

Substitution of Level 2 equations into their corresponding Level 1 terms in Equation (1) yields the following reduced-form equation with a complex error structure: 


$$
\begin{gathered}
Y_{i j}=\gamma_{00}+\gamma_{01} \times \text { PHYGOOD }_{j}+\gamma_{02} \times \text { GOVT }_{j}+\gamma \times \text { INFORMATION }_{j} \\
+\gamma_{04} \times \text { TRANSACTION }_{j}+\gamma_{10} \times \text { CONT }_{i j}+\gamma_{20} \times \text { FUNC }_{i j}+\gamma_{30} \times \text { STRU }_{i j} \\
+\left[\gamma_{11} \times \text { PHYGOOD }_{j}+\gamma_{12} \times \text { GOVT }_{j}+\gamma_{13} \times \text { INFORMATION }_{j}+\gamma_{14}\right. \\
\left.\times \text { TRANSACTION }_{j}\right] * \text { CONT }_{i j}+\left[\gamma_{21} \times \text { PHYGOOD }_{j}+\gamma_{22} \times \text { GOVT }_{j}\right. \\
\left.+\gamma_{23} \times \text { INFORMATION }_{j}+\gamma_{24} \times \text { TRANSACTION }_{j}\right] \\
\times \text { FUNC }_{i j}+\left[u_{0 j}+u_{1 j} \times \text { CONT }_{i j}+u_{2 j} \times \text { FUNC }_{i j}+r_{i j}\right] .
\end{gathered}
$$

To estimate the coefficients in this equation properly, we account for differential precision of the information provided by each Web site using the generalized least squares procedure. Finally, because the number of customers and within-Web site parameters vary across Web sites, we employ an iterative technique using an expectation maximization algorithm and Fisher scoring to obtain maximum likelihood estimates of Level 1 and Level 2 variance components [54].

HLM analysis provides three kinds of parameter estimates-empirical Bayes or shrunken estimates of randomly varying Level 1 coefficients (i.e., within-Web site coefficients), generalized least squares estimates of the Level 2 coefficients (i.e., acrossWeb sites coefficients), and maximum likelihood estimates of the variance and covariance components [54]. The estimates of Level 1 coefficients for each Web site are optimal composites of an estimate based on data from that Web site and an estimate based on data from other Web sites.

Before estimating our models, we centered the variables in accordance with guidelines that Raudenbush and Bryk [53] suggest. In the within-Web site model, we allow only content and functionality ratings to vary across Web sites; thus, we group-meancenter content and functionality variables [53]. The remaining predictor (i.e., Web site structure) does not show much variation across Web sites; thus, we constrain its variance to be zero and grand-mean-center this variable. Use of such centering decisions at Level 1 implies that the intercept at Level 1 represents mean customer loyalty for a customer with an average rating of content and functionality within a Web site and an average rating of structure in the overall sample across Web sites. At Level 2, we grand-mean-center all continuous variables but leave binary variables (e.g., GOVT, PHYGOOD) uncentered for an easier interpretation of the results.

\section{Results}

TABLE 3 PRESENTS DETAILED RESULTS from the estimation of the HLM models. From the results of our fully unconditional model (see Table 3), we find that ICC is 17.09 percent for the customer referral model. In other words, more than 17 percent of the variance in referral likelihood lies across individual Web sites. To understand the nature of systematic variation of more than 17 percent in the dependent variable across 
Table 3. Results of HLM Estimation for Referral Models

\begin{tabular}{|c|c|c|c|}
\hline & & \multicolumn{2}{|c|}{$\begin{array}{l}\text { Customer loyalty } \\
\text { (referral likelihood) }\end{array}$} \\
\hline & & Coefficient & $\begin{array}{c}\text { Standard } \\
\text { error }\end{array}$ \\
\hline \multicolumn{4}{|l|}{ Intercept } \\
\hline INTRCPT2 & $\gamma_{00}$ & $7.672^{\star \star \star}$ & 0.084 \\
\hline PHYGOOD & $\gamma_{01}$ & -0.179 & 0.135 \\
\hline GOVT & $\gamma_{02}$ & $0.240^{*}$ & 0.126 \\
\hline INFORMATION & $\gamma_{03}$ & 0.186 & 0.217 \\
\hline TRANSACTION & $\gamma_{04}$ & $0.732^{\star \star \star}$ & 0.186 \\
\hline \multicolumn{4}{|l|}{ Content (CONT) slope } \\
\hline INTRCPT2 & $\gamma_{10}$ & $0.268^{\star \star \star}$ & 0.021 \\
\hline PHYGOOD & $\gamma_{11}$ & $-0.094^{\star \star}$ & 0.042 \\
\hline GOVT & $\gamma_{12}$ & $-0.053^{\star}$ & 0.030 \\
\hline INFORMATION & $\gamma_{13}$ & $0.363^{\star \star \star}$ & 0.048 \\
\hline TRANSACTION & $\gamma_{14}$ & $-0.260^{\star \star \star}$ & 0.041 \\
\hline \multicolumn{4}{|l|}{ Functionality $(F U N C)$ slope } \\
\hline INTRCPT2 & $\gamma_{20}$ & $0.508^{\star \star \star}$ & 0.017 \\
\hline PHYGOOD & $\gamma_{21}$ & 0.038 & 0.048 \\
\hline GOVT & $\gamma_{22}$ & -0.001 & 0.025 \\
\hline INFORMATION & $\gamma_{23}$ & $-0.223^{\star \star *}$ & 0.049 \\
\hline TRANSACTION & $\gamma_{24}$ & $0.124^{\star * *}$ & 0.042 \\
\hline \multicolumn{4}{|l|}{ Structure (STRU) slope } \\
\hline INTRCPT2 & $\gamma_{30}$ & $0.238^{\star \star *}$ & 0.018 \\
\hline \multirow{2}{*}{\multicolumn{3}{|c|}{$\begin{array}{l}\text { Deviance (-2 log likelihood) } \\
\text { Intraclass correlation (ICC) (percent) }\end{array}$}} & \\
\hline & & & 17.09 \\
\hline \multicolumn{3}{|c|}{ Proportion of variance explained at Level 1 (in percent) } & 64.35 \\
\hline \multicolumn{3}{|c|}{ Proportion of variance explained in intercept (in percent) } & 90.61 \\
\hline \multicolumn{3}{|c|}{ Proportion of variance explained in content slope (in percent) } & 79.19 \\
\hline \multicolumn{3}{|c|}{ Proportion of variance explained in functionality slope (in percent) } & 73.23 \\
\hline$* * * p<0.01 ; * * p<0.05 ; * p$ & & & \\
\hline
\end{tabular}

Web sites, it is necessary to model this variation using an HLM approach to derive valid conclusions.

We next explain variance within Web sites through customer-level variables of content, functionality, and structure. Our random coefficients regression model (withinWeb site model) explain a substantial 64.35 percent of variance across customers within Web sites in referral likelihood. We also find that both intercept (mean measures of customer loyalty) and slopes (the relationship among content, functionality, customer loyalty) continue to vary significantly across Web sites, even after we control for within-Web site predictors (content, functionality, and structure).

Finally, we model the variance across Web sites through Web site-level variables. We find that our Web site-level predictor variables explain a significant amount of 
variance in intercepts and slopes across Web sites. By comparing the estimation of variance components from our random coefficient model and from our full model, we determine the proportion of the between-Web sites variance explained by our full model having predictors at Level 2. As Table 3 shows, our between-Web sites model for intercept explains 90.61 percent of the variance in mean referral likelihood. Our modeling of the content and functionality slopes at Level 2 also explains a significant variance in these slopes across Web sites (79.19 percent and 73.23 percent variance in content and functionality slopes, respectively).

\section{Effect of Content, Functionality, and Structure on Customer Loyalty}

As H1a through H1c predicted, we find (see Table 3) that content $\left(\gamma_{10}=0.268, p<\right.$ $0.01)$, functionality $\left(\gamma_{20}=0.508, p<0.01\right)$, and structure $\left(\gamma_{30}=0.238, p<0.01\right)$ have a significant and positive influence on referral likelihood. We observe that, on average, functionality has considerably more influence on customer loyalty than does content or structure (i.e., $\gamma_{20}>\gamma_{10}$ and $\gamma_{30}$ ).

Next, we interpret the results of intercept and slope modeling at Level 2. In terms of intercept modeling results, Table 3 shows that the mean referral likelihood is higher for government Web sites than for commercial Web sites $\left(\gamma_{02}=0.240, p<0.1\right)$. Government departments typically have less customer satisfaction than commercial enterprises [26]; one reason for this result may be that government Web sites carry unique information that cannot be obtained elsewhere. ${ }^{2}$ Alternatively, the e-government initiatives that aim to make all information and services transparent may have exceeded customer expectations. There is a need for further research to test these alternative explanations. We also find that transaction-oriented Web sites are likely to have higher customer loyalty $\left(\gamma_{04}=0.732, p<0.01\right)$, beyond the prediction of customer loyalty based on a customer's evaluation of the Web site's functionality. This result shows that contextual effects are important in explaining people's relative loyalty to Web sites, and it points to the importance of modeling contextual effects that are often ignored in conventional ordinary least squares or structural equation modeling analyses.

\section{The Moderating Effect of Business Domain}

Table 3 also shows the results of content $\left(\gamma_{11}\right.$ through $\left.\gamma_{14}\right)$ and functionality $\left(\gamma_{21}\right.$ through $\gamma_{24}$ ) slopes modeled at the Web site level. As H2a predicted, we find that the contentloyalty relationship is less steep for government Web sites $\left(\gamma_{12}=-0.053, p<0.10\right)$ than for commercial Web sites. One reason for this result may be that government Web sites have higher levels of customer loyalty; thus, further improvements in content for such Web sites is not likely to be as beneficial as in the case of commercial Web sites that have lower levels of customer loyalty. We do not find support for H2b, 
which predicted a moderating effect of GOVT on the functionality-loyalty relation$\operatorname{ship}\left(\gamma_{22}=-0.001\right.$, not significant [n.s.]).

We find support for H3a because the content-loyalty relationship is less steep for Web sites that sell physical goods $\left(\gamma_{11}=-0.094, p<0.05\right)$ than for Web sites that offer services. This result provides support for the argument that IT interventions (e.g., the provision of services through Web sites) are likely to apply more to services than to goods [4]. We do not find support for H3b, which predicted a moderating effect of PHYGOOD on the functionality-loyalty relationship $\left(\gamma_{21}=0.038\right.$, n.s. $)$.

Our results support $\mathrm{H} 4 \mathrm{a}$ and $\mathrm{H} 4 \mathrm{~b}$, which predicted a moderating effect of INFORMATION and TRANSACTION Web sites on the content-loyalty and functionality-

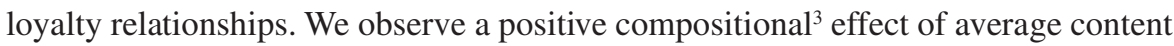
rating on content slope $\left(\gamma_{13}=0.363, p<0.01\right)$ and a negative compositional effect of average functionality on content slope $\left(\gamma_{14}=-0.260, p<0.01\right)$. These compositional effects mirror the compositional effects for functionality slope; the average functionality of a Web site positively affects functionality slope $\left(\gamma_{24}=0.124, p<0.01\right)$, and the average content of a Web site negatively affects functionality slope $\left(\gamma_{23}=-0.223, p<\right.$ $0.01)$.

To summarize the HLM analyses, we find that both the intercepts and slopes vary significantly across Web sites. This finding, which is based on a systematic and rigorous analysis across $43 \mathrm{Web}$ sites, provides empirical support for the assertion that the relative importance of Web site features varies significantly across Web sites and that such variation can often be of substantive interest. We explain significant variance in the measure of customer loyalty through Level 1 or individual Web site predictors, such as content, functionality, and structure. At Level 2, we explain substantial variance in the mean customer loyalty measure (intercept) through Web site domain and compositional predictor variables. We explain 79.19 percent and 73.23 percent variance in content and functionality slopes, respectively, across Web sites through Web site-level (Level 2) predictor variables.

\section{HLM Versus Moderated Regression}

To understand the added value of HLM analyses, we also estimated our models using a conventional moderated regression approach to compare the results with our HLM analyses. Table 4 shows that a conventional moderated regression approach can yield biased parameter estimates (refer to column (5), which compares differences in coefficients), with the bias being as high as 300 percent for one of the parameters in this study. Furthermore, a moderated regression approach usually underestimates the standard errors and thus may lead to the rejection of null hypotheses more frequently than if the nested nature of data is considered, as we do in our HLM analyses (refer to column (6), which compares differences in standard errors). These problems would be even more pronounced for studies that use smaller sample sizes than we used in this research. This study points to a need for caution when interpreting the results of previous studies that did not account for the nested nature of data. 


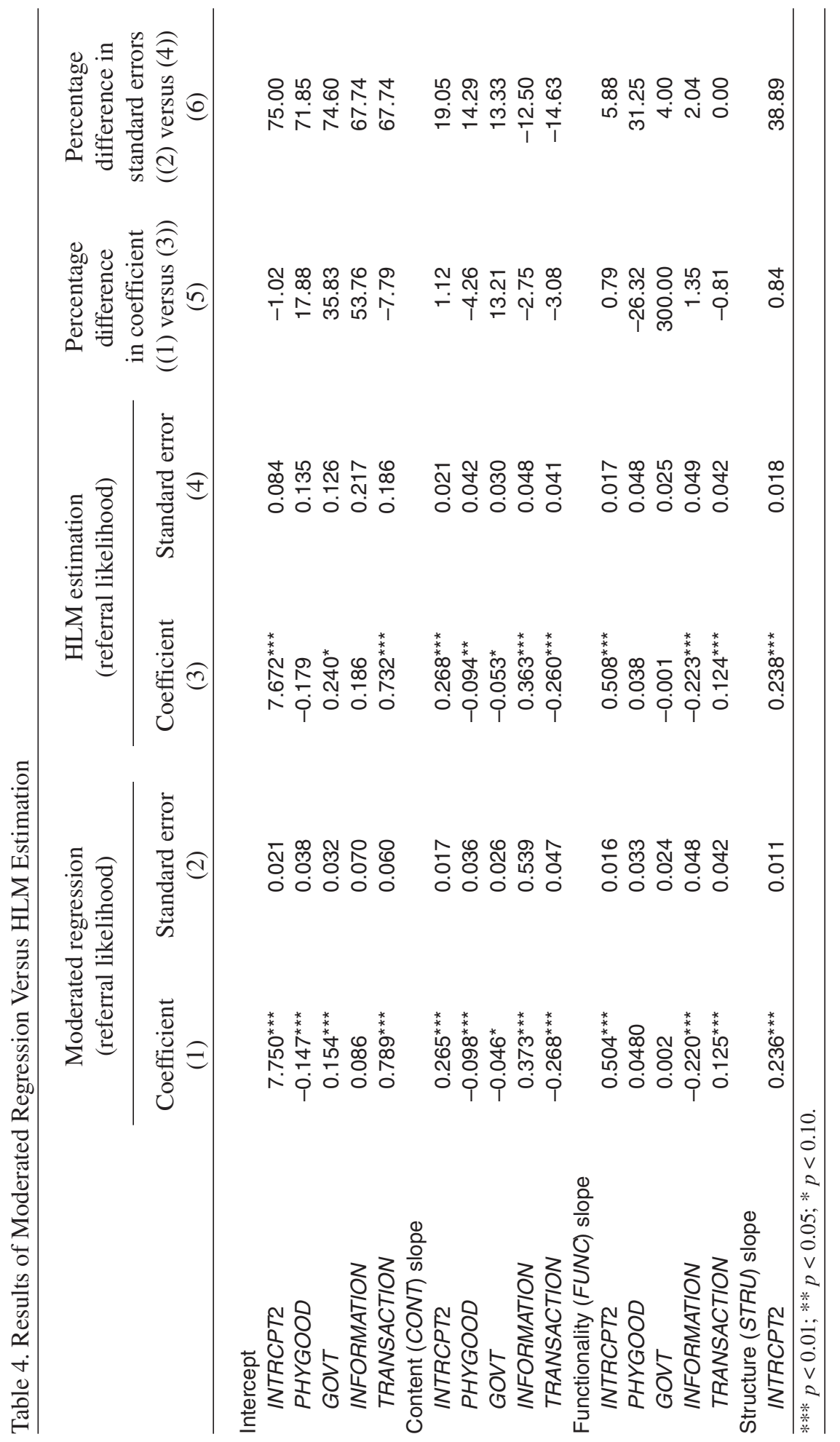


Table 5. Results for Return Likelihood (an Alternative Measure of Customer Loyalty)

\begin{tabular}{|c|c|c|c|}
\hline \multirow[b]{2}{*}{ Variable } & & \multicolumn{2}{|c|}{ Return likelihood } \\
\hline & & Coefficient & $\begin{array}{l}\text { Standard } \\
\text { error }\end{array}$ \\
\hline Intercept & $\beta_{0}$ & & \\
\hline INTRCPT2 & $\gamma_{00}$ & $8.094^{\star \star *}$ & 0.183 \\
\hline PHYGOOD & $\gamma_{01}$ & -0.309 & 0.201 \\
\hline GOVT & $\gamma_{02}$ & 0.273 & 0.225 \\
\hline INFORMATION & $\gamma_{03}$ & 0.065 & 0.417 \\
\hline TRANSACTION & $\gamma_{04}$ & $0.702^{*}$ & 0.384 \\
\hline Content (CONT) slope & $\beta_{1}$ & & \\
\hline INTRCPT2 & $\gamma_{10}$ & $0.274^{\star \star \star}$ & 0.025 \\
\hline PHYGOOD & $\gamma_{11}$ & $-0.122^{\star \star \star}$ & 0.044 \\
\hline GOVT & $\gamma_{12}$ & -0.018 & 0.046 \\
\hline INFORMATION & $\gamma_{13}$ & $0.504^{* * *}$ & 0.062 \\
\hline TRANSACTION & $\gamma_{14}$ & $-0.378^{\star \star \star}$ & 0.056 \\
\hline Functionality (FUNC) slope & $\beta_{2}$ & & \\
\hline INTRCPT2 & $\gamma_{20}$ & $0.399^{\star \star \star}$ & 0.029 \\
\hline PHYGOOD & $\gamma_{21}$ & $0.104^{\star *}$ & 0.049 \\
\hline GOVT & $\gamma_{22}$ & -0.008 & 0.046 \\
\hline INFORMATION & $\gamma_{23}$ & $-0.210^{\star *}$ & 0.091 \\
\hline TRANSACTION & $\gamma_{24}$ & 0.078 & 0.079 \\
\hline Structure (STRU) slope & $\beta_{3}$ & & \\
\hline INTRCPT2 & $\gamma_{30}$ & $0.191^{\star * *}$ & 0.015 \\
\hline Deviance (-2 log likelihood) & & $46,014.2$ & \\
\hline Intraclass correlation (ICC) (in percent) & & & 18.18 \\
\hline $\begin{array}{l}\text { Proportion of variance } \\
\text { explained at Level } 1 \text { (in percent) }\end{array}$ & $R$ & & 58.80 \\
\hline $\begin{array}{l}\text { Proportion of variance explained } \\
\text { in intercept (in percent) }\end{array}$ & $U_{0}$ & & 65.60 \\
\hline $\begin{array}{l}\text { Proportion of variance explained } \\
\text { in content slope (in percent) }\end{array}$ & $U_{1}$ & & 56.97 \\
\hline $\begin{array}{l}\text { Proportion of variance explained } \\
\text { in functionality slope (in percent) }\end{array}$ & $U_{2}$ & & 54.67 \\
\hline$* * * p<0.01 ; * * p<0.05 ; * p<0.10$ & & & \\
\hline
\end{tabular}

\section{Does Higher Referral Also Mean Higher Return Likelihood?}

We also used return likelihood as an alternative measure of customer loyalty to check the robustness of our results. Table 5 shows that though many of the parameter estimates of the return likelihood model are broadly similar to the referral likelihood model, there are some notable differences that require some discussion. First, although the GOVT coefficient is positive and statistically significant in the referral model in Table $3\left(\gamma_{02}=0.240, p<0.10\right)$, this coefficient is statistically nonsignificant in the return model in Table 5. This difference is noteworthy because it suggests that 
though government Web sites are likely to get more referrals because of their monopoly on relevant content, in and of itself, this does not make more customers return to government Web sites.

Second, although the content-loyalty relationship is negative for government Web sites in the referral model in Table $3\left(\gamma_{12}=-0.053, p<0.10\right)$, this coefficient is statistically nonsignificant in the return model in Table 5 . This result suggests that though improvement in Web site content has a negative effect on consumer referral, content improvement does not affect consumers' return likelihood for government Web sites. These results echo the argument that government Web sites have the monopoly nature to generate some unique behaviors.

Finally, we observe that though PHYGOOD does not have a moderating effect on the functionality-loyalty relationship $\left(\gamma_{21}=0.038\right.$, n.s. $)$ in the referral model in Table 3 , this coefficient is positive and statistically significant in the return model in Table 5 $\left(\gamma_{21}=0.104, p<0.05\right)$. This result suggests that functionality improvements are likely to lead to more visitors returning to goods-related Web sites, though these Web sites do not get more referrals. Table 6 provides a summary of estimation results for all the hypotheses.

\section{Discussion}

OUR GOAL WAS TO TEST EMPIRICALLY the effect of Web site design elements on customer loyalty and to understand how the relationship between design elements and customer loyalty varies in light of the business domain in which the Web sites are nested. Next, we discuss key findings, limitations, and the implications of this study.

\section{Findings}

This research extends previous work on the validation of Web site metrics by rigorously testing the effect of content, functionality, and structure design characteristics on customer loyalty, accounting for the moderating effect of business domains. In contrast to previous findings from laboratory or field-based experiments that simulate online consumer behavior, this research used data collected from actual online customers to test the substantive hypotheses. Our analysis of data collected from more than 12,000 customers across $43 \mathrm{Web}$ sites indicates that content, functionality, and structure have a significant and positive effect on multiple measures of loyalty. Our analysis of Web site characteristics at the consumer level reinforces the results reported in prior usability and scale validation studies. We show the effect of usability characteristics (i.e., content, functionality, and structure) on customer loyalty.

An even more important aspect of our analysis lies in studying and modeling the relationship between usability characteristics and customer loyalty with Web sitelevel variables. Our results suggest that the effect of content and functionality on customer loyalty varies across business domains. For example, we find that the relationship between Web site content and customer loyalty is stronger for commercial Web sites than for government Web sites. We also find that the relationship between content and 
Table 6. Summary of Hypotheses and Results

\begin{tabular}{|c|c|c|}
\hline Hypothesis & Description & Result \\
\hline $\mathrm{H} 1 \mathrm{a}$ & $\begin{array}{l}\text { Higher scores on perceived quality of Web site } \\
\text { content are positively associated with higher } \\
\text { customer loyalty. }\end{array}$ & Supported \\
\hline $\mathrm{H} 1 \mathrm{~b}$ & $\begin{array}{l}\text { Higher scores on perceived Web site functionality } \\
\text { are positively associated with higher customer } \\
\text { loyalty. }\end{array}$ & Supported \\
\hline $\mathrm{H} 1 \mathrm{c}$ & $\begin{array}{l}\text { Higher scores on perceived Web site structure are } \\
\text { positively associated with higher customer loyalty. }\end{array}$ & Supported \\
\hline $\mathrm{H} 2 \mathrm{a}$ & $\begin{array}{l}\text { Effect of Web site content on customer loyalty is } \\
\text { higher for commercial Web sites than for } \\
\text { government Web sites. }\end{array}$ & Supported \\
\hline $\mathrm{H} 2 \mathrm{~b}$ & $\begin{array}{l}\text { Effect of Web site functionality on customer loyalty } \\
\text { is higher for commercial Web sites than for } \\
\text { government Web sites. }\end{array}$ & Not supported \\
\hline $\mathrm{H} 3 \mathrm{a}$ & $\begin{array}{l}\text { Effect of Web site content on customer loyalty is } \\
\text { higher for Web sites that offer services than those } \\
\text { that offer goods. }\end{array}$ & Supported \\
\hline $\mathrm{H} 3 \mathrm{~b}$ & $\begin{array}{l}\text { Effect of Web site functionality on customer loyalty } \\
\text { is higher for Web sites that offer services than } \\
\text { those that offer goods. }\end{array}$ & Not supported \\
\hline $\mathrm{H} 4 \mathrm{a}$ & $\begin{array}{l}\text { Web site content will have a greater effect on } \\
\text { customer loyalty to information Web sites than to } \\
\text { transaction Web sites. }\end{array}$ & Supported \\
\hline $\mathrm{H} 4 \mathrm{~b}$ & $\begin{array}{l}\text { Web site functionality will have a greater effect on } \\
\text { customer loyalty to transaction Web sites than to } \\
\text { information Web sites. }\end{array}$ & Supported \\
\hline
\end{tabular}

customer loyalty is stronger for services-related Web sites than for goods-related Web sites. Finally, we find that the relationship between content and customer loyalty is stronger for information-oriented Web sites than for transaction-oriented Web sites. However, the relationship between functionality and customer loyalty is stronger for transaction-oriented Web sites than for information-oriented Web sites.

We do not find support for the notion that the effect of functionality on customer loyalty is higher for commercial Web sites than for government Web sites. One explanation for this result could be that visitors to government Web sites may be primarily interested in information content, and therefore functionality improvements in government Web sites do not have an effect on customer loyalty. Likewise, we do not find support for the notion that the effect of functionality on customer loyalty is higher for services-related Web sites than for goods-related Web sites. One explanation for this result could be that visitors may be using the goods-related Web sites only for product review and research without actually buying goods from such Web sites, and thus they do not experience the functionality of such Web sites fully enough for us to be able to detect the effect on customer loyalty. There is a need for further research to test and validate these explanations. 
Among other findings, we note that government Web sites enjoy greater word-ofmouth effect than commercial Web sites. Finally, transaction-oriented Web sites tend to score higher on mean customer loyalty than information-oriented Web sites.

One of the principal contributions of this research is that it systematically studies the effect of industry and domain effects that have not received as much attention in previous research. By considering the domain effects when studying the effect of design elements, we obtain a more complete picture of the trade-offs involved in Web site redesign efforts. Our use of broad categorization schemes to classify Web sites at the business domain level and the richness of the customer-level data enable us to derive with generalizable findings that are applicable to a wide variety of Web sites.

Although this study uses consumer-level data, the findings echo some of the fundamental insights that characterize firm-level research at a higher level. For example, the finding that information-oriented Web sites are better off making further improvements in their content and that transaction-oriented Web sites are better off making further improvements in their functionality parallels the advice of "sticking to knitting," or exploiting core competencies, which is often invoked to guide managerial focus. Our research provides one example of the presence of some unifying themes that may encompass microlevel Web site redesign decisions and higher-level decision making in the context of the management of IT or other firm resources. We believe that the exploration of such unifying themes is essential for the progress of the IS discipline to arrive at certain key principles for managing IT resources in general.

\section{Limitations}

Before discussing the implications of our findings, we acknowledge the following limitations of this study. First, we used self-reported measures of customer loyalty. Further research should strive to validate our findings using more objective measures of customer loyalty, such as actual revisit or repeat purchase behavior. There is a need to develop these and other measures of the business value of Web sites and to understand the relevant factors for exploiting opportunities that Internet technologies present for enhancing business value [30]. Second, we focused on the effect of three key Web site design elements - content, functionality, and structure-on customer loyalty. To obtain a more complete understanding, there is a need to examine the effect of other and more specific design elements, such as search functionality, and privacy protection mechanisms, on customer loyalty.

\section{Implications for Designing Web Sites for Customer Loyalty and Future Research}

This study provides several insights that have implications for the effect of Web site design on customer loyalty. Perhaps the most important finding of this research is that there are trade-offs involved in making redesign improvements. Our results suggest that more of everything is not better, even if it were feasible. For example, the finding that mean referral ratings are higher for Web sites with a higher average score on 
functionality transaction does not mean that managers should make indiscriminate improvements in the functionality of their Web sites to attract and retain customers. Managers also need to consider the business domain in which their Web site is operating to understand the relative effect of content or functionality improvement. For example, physical goods Web sites show weaker content-referral likelihood relationships than services Web sites, and government Web sites show weaker content-referral likelihood relationships than commercial Web sites.

Our results also suggest that the content-loyalty relationship is stronger for information-oriented Web sites than for transaction-oriented Web sites. However, the functionality-loyalty relationship is stronger for transaction-oriented Web sites than for information-oriented Web sites. In other words, sticking to core competencies may be a good strategy for redesign because information-oriented Web sites are likely to gain more from improvements in content than from improvements in functionality, whereas transaction-oriented Web sites are likely to gain more from improvements in functionality than from improvements in content. Managers can put their limited resources to better use by understanding these moderating effects and by investing judiciously in improving the appropriate characteristics.

However, this implication must be viewed with caution because our analysis does not include a cost-benefit analysis in exploring the effects of design element improvements on customer loyalty. There is a limit to the value of improvements in content for information-oriented sites and improvements in functionality for transaction-oriented sites. At some high level of content quality, the marginal benefit of improving content might be outweighed by the marginal cost; alternatively, the net benefit of making further improvements to content may be outweighed by the net benefit of making further improvements to functionality for information-oriented sites. Whether it is better to improve content (rather than functionality) for an information-oriented Web site depends on where the Web site is on the marginal benefit curve. This suggests the importance of the level of content and functionality in determining which element to improve. As such, managers must consider these complex trade-offs when they decide on improvements for the desired effect on firm performance. ${ }^{4}$

Finally, we find that government Web sites are more likely to receive referrals than are commercial Web sites. Although one explanation for this finding may be that customers have fewer choices to obtain information about government rules and regulations and they are more likely to refer these Web sites to their friends despite lower ratings on design elements, this finding also suggests that firms need to catch up with the public sector by making Web site-related improvements to bolster customer loyalty. These managerial actions may contribute to the continued growth of e-commerce.

We suggest several directions for further research. First, a natural extension of this research is to assess the extent to which a positive Web site experience leads to greater sales from offline channels. This will be an interesting area of inquiry because anecdotal evidence suggests that many consumers conduct their initial search online but ultimately purchase offline.

Second, our research relies on a large data set of actual online customers to generalize the effect of Web site design elements on customer loyalty; such a research 
design does not permit the study of evolving customer behavior, because customer expectations keep changing as Web sites evolve. Thus, there is a need for in-depth qualitative studies that use ethnography, participant observation, and existential phenomenology approaches to discover other determinants of customer loyalty in online environments to keep pace with changes in consumer behavior.

Third, Web site design elements are also likely to have an effect on customers' propensity to trust a Web site. Further research may focus on the effect of such design elements on trust in online firms [9]. Finally, whereas our study considers Web site heterogeneity and attempts to model that using several Web site-level variables, further research may examine how our findings, which are based on U.S. Web sites, vary across national and cultural contexts.

To conclude, Web sites are becoming increasingly important as marketing and sales channels. It is not enough merely to build and host a Web site. Instead, it is imperative to have an online presence that continuously responds to customers' visit patterns and feedback. Firms need to know which aspects of Web site characteristics are important to their customers and how they can increase customer loyalty to their Web sites. Responsive improvements need to be guided by a close monitoring and analysis of customer feedback data generated through customer surveys at periodic intervals. This research provides some insights into the determinants of customer loyalty for Web sites across industry sectors. From a theoretical perspective, this study develops the notion of Web site embeddedness in particular business domains to provide a contextual understanding of redesign decisions to improve customer loyalty. From a methodological perspective, this paper demonstrates the use of HLM to address the multilevel nature of research questions and data by considering the nesting of a Web site in a particular business domain when evaluating the relative importance of design elements. We hope that the theory, method, and the results of this study will catalyze further research to enhance the understanding of the drivers of customer loyalty, an issue that has become critical for the survival of firms in a competitive economy.

Acknowledgments: The authors thank T.P. Liang, Mohan Tanniru, and the two anonymous $J M I S$ reviewers for their guidance and helpful comments to improve this paper. They thank Foresee Results for providing necessary data for this research. In particular, they thank Larry Freed and Anne Kippe for their generous help. The authors thank Michel Wedel, Valerie E. Lee, and Julie Garcia for helpful comments on previous versions of this paper. They thank Eli Dragolov for providing excellent research assistance. A research-in-progress version of this paper was presented at the International Conference on Information Systems (ICIS) in 2003, and the authors thank J.P. Shim, ICIS reviewers, and participants for their helpful comments. Financial support for this study was provided in part by the R.H. Smith School of Business at the University of Maryland and a Michael R. and Mary Kay Hallman fellowship at the Ross School of Business at the University of Michigan.

\section{NoTES}

1. We do not consider the moderating effect of business domains on the relationship between Web site structure and customer loyalty for the sake of parsimony and because of the 
structure of our data. It is common in studies that use HLM not to model all the slope relationships; we discuss this in the "Method" section.

2. We thank an anonymous reviewer for suggesting this alternative explanation.

3. Such compositional effects are also observed in the education research, and detection of such compositional effects is one of the advantages of the HLM approach [53].

4. We thank an anonymous reviewer for this discussion.

\section{REFERENCES}

1. Agarwal, R., and Venkatesh, V. Assessing a firm's Web presence: A heuristic evaluation procedure for the measurement of usability. Information Systems Research, 13, 2 (2002), $168-186$.

2. Anderson, E.W.; Fornell, C.; and Lehmann, D.R. Customer satisfaction, market share, and profitability: Findings from Sweden. Journal of Marketing, 58, 3 (July 1994), 53-66.

3. Anderson, E.W.; Fornell, C.; and Mazvancheryl, S.K. Customer satisfaction and shareholder value. Journal of Marketing, 68, 4 (October 2004), 172-185.

4. Anderson, E.W.; Fornell, C.; and Rust, R.T. Customer satisfaction, productivity, and profitability: Differences between goods and services. Marketing Science, 16, 2 (1997), 129-145.

5. Ang, S.; Slaughter, S.A.; and Ng, K.Y. Human capital and institutional determinants of information technology compensation: Modeling multilevel and cross-level interactions. Management Science, 48, 11 (2002), 1427-1445.

6. Balasubramanian, S.; Konana, P.; and Menon, N.M. Customer satisfaction in virtual environments: A study of online investing. Management Science, 49, 7 (2003), 871-889.

7. Bardhan, I.R.; Whitaker, J.; and Mithas, S. Information technology, production process outsourcing and manufacturing plant performance. Journal of Management Information Systems, 23, 2 (Fall 2006), 13-40.

8. Barua, A., and Mukhopadhyay, T. Information technology and business performance: Past, present, and future. In R.W. Zmud (ed.), Framing the Domains of Information Technology Management: Projecting the Future . . Through the Past. Cincinnati, OH: Pinnaflex, 2000, pp. 65-84.

9. Bhattacherjee, A. Individual trust in online firms: Scale development and initial test. Journal of Management Information Systems, 19, 1 (Summer 2002), 211-241.

10. Bolton, R.N.; Kannan, P.K.; and Bramlett, M.D. Implications of loyalty program membership and service experiences for customer retention and value. Journal of the Academy of Marketing Science, 28, 1 (2000), 95-108.

11. Brown, T.J.; Barry, T.E.; Dacin, P.A.; and Gunst, R.F. Spreading the word: Investigating antecedents of consumers' positive word-of-mouth intentions and behaviors in a retailing context. Journal of the Academy of Marketing Science, 33, 2 (2005), 123-138.

12. Brynjolfsson, E. The contribution of information technology to consumer welfare. Information Systems Research, 7, 3 (1996), 281-300.

13. Brynjolfsson, E., and Hitt, L. The customer counts. InformationWeek (September 9, 1996), 48 (available at www.informationweek.com/596/96mit.htm).

14. Brynjolfsson, E., and Hitt, L.M. Beyond the productivity paradox. Communications of the ACM, 41, 8 (1998), 49-55.

15. Caudle, S.L.; Gorr, W.L.; and Newcomer, K.E. Key information systems management issues for the public sector. MIS Quarterly, 15, 2 (1991), 171-188.

16. Chiasson, M.W., and Davidson, E. Taking industry seriously in information systems research. MIS Quarterly, 29, 4 (2005), 591-605.

17. Coper, L. Academic matters. Optimize, 4, 10 (October 2005), 78-79.

18. Daft, R.L., and Lengel, R.H. Organizational information requirements, media richness and structural design. Management Science, 32, 5 (1986), 554-571.

19. Davern, M.; Te'eni, D.; and Moon, J. Content versus structure in information environments: A longitudinal analysis of Website preferences. In W.J. Orlikowski, S. Ang, P. Weill, H.C. Krcmar, and J.I. DeGross (eds.), Proceedings of the Twenty-First International Conference on Information Systems. Atlanta: Association for Information Systems, 2000, pp. 564-570. 
20. Davis, F. Perceived usefulness, perceived ease of use, and user acceptance of information technology. MIS Quarterly, 13, 3 (1989), 319-340.

21. Dellarocas, C. The digitization of word of mouth: Promise and challenges of online feedback mechanisms. Management Science, 49, 10 (2003), 1407-1424.

22. Devaraj, S.; Fan, M.; and Kohli, R. Antecedents of B2C channel satisfaction and preference: Validating e-commerce metrics. Information Systems Research, 13, 3 (2002), 316-333.

23. Drolet, A.L., and Morrison, D.G. Do we really need multiple-item measures in service research? Journal of Service Research, 3, 3 (2001), 196-204.

24. Fornell, C. The quality of economic output: Empirical generalizations about its distribution and relationship to market share. Marketing Science, 14, 3 (1995), G203-211.

25. Fornell, C.; Mithas, S.; Morgeson, F.; and Krishnan, M.S. Customer satisfaction and stock prices: High returns, low risk. Journal of Marketing, 70, 1 (2006), 3-14.

26. Fornell, C.; Johnson, M.D.; Anderson, E.W.; Cha, J.; and Bryant, B.E. The American customer satisfaction index: Nature, purpose, and findings. Journal of Marketing, 60, 4 (1996), $7-18$.

27. Greene, W.H. Econometric Analysis, 4th ed. Upper Saddle River, NJ: Prentice Hall, 2000.

28. Gruca, T., and Rego, L. Customer satisfaction, cash flow and shareholder value. Journal of Marketing, 69, 3 (2005), 115-130.

29. Hitt, L.M., and Brynjolfsson, E. Productivity, business profitability, and consumer surplus: Three different measures of information technology value. MIS Quarterly, 20, 2 (1996), $121-142$.

30. Hoffman, D.L., and Novak, T.P. Marketing in hypermedia computer-mediated environments: Conceptual foundations. Journal of Marketing, 60, 3 (July 1996), 50-68.

31. Hoffman, D.L.; Novak, T.P.; and Chatterjee, P. Commercial scenarios for the Web: Opportunities and challenges. Journal of Computer-Mediated Communication, 1, 3 (1995), 5068.

32. Hofmann, D.A. An overview of the logic and rationale of hierarchical linear models. Journal of Management, 23, 6 (1997), 723-744.

33. Hoos, I.R. Information systems and public planning. Management Science, 17, 10 (1971), B658-B671.

34. Jayachandran, S.; Sharma, S.; Kaufman, P.; and Raman, P. The role of relational information processes and technology use in customer relationship management. Journal of Marketing, 69, 4 (October 2005), 177-192.

35. Kalin, S. Usability: Mazed and confused. CIO Web Business Magazine (April 1, 1999) (available at www.cio.com/archive/webbusiness/040199_use.html).

36. Kauffman, R.J., and Weill, P., An evaluative framework for research on the performance effects of information technology investments. In J.I. DeGross, J.C. Henderson, and B.R. Konsynski (eds.), Proceedings of the Tenth International Conference on Information Systems. Atlanta: Association for Information Systems, 1989, pp. 377-388.

37. Kim, J.; Lee, J.; Han, K.; and Lee, M. Businesses as buildings: Metrics for the architectural quality of Internet business. Information Systems Research, 13, 3 (2002), 239-254.

38. Koufaris, M. Applying the technology acceptance model and flow theory to online consumer behavior. Information Systems Research, 13, 2 (2002), 205-223.

39. Liang, T.-P., and Huang, J.-S. An empirical study on consumer acceptance of products in electronic markets: A transaction cost model. Decision Support Systems, 24, 1 (November 1998), 29-43.

40. Liang, T.-P., and Lai, H.-J. Effect of store design on consumer purchases: An empirical study of on-line bookstores. Information \& Management, 39, 6 (May 2002), 431-444.

41. Liang, T.-P.; Lin, C.-Y.; and Chen, D.-N. Effects of electronic commerce models and industrial characteristics on firm performance. Industrial Management \& Data Systems, 104, 7 (2004), 538-545.

42. Little, R.J., and Rubin, D.B. Statistical Analysis with Missing Data. New York: John Wiley \& Sons, 1997.

43. McKinney, V.; Yoon, K.; and Zahedi, F. The measurement of Web-customer satisfaction: An expectation and disconfirmation approach. Information Systems Research, 13, 3 (2002), $296-315$. 
44. Mills, P.K., and Moberg, D.J. Perspectives on the technology of service operations. Academy of Management Review, 7, 3 (1982), 467-478.

45. Mithas, S., and Jones, J.L. Do auction parameters affect buyer surplus in e-auctions for procurement? Production and Operations Management, 16, 3 (2007), forthcoming.

46. Mithas, S.; Almirall, D.; and Krishnan, M.S. Do CRM systems cause one-to-one marketing effectiveness? Statistical Science, 21, 2 (2006), 223-233.

47. Mithas, S.; Krishnan, M.S.; and Fornell, C. Effect of information technology investments on customer satisfaction: Theory and evidence. Working Paper, Ross School of Business, University of Michigan, Ann Arbor, 2005.

48. Mithas, S.; Krishnan, M.S.; and Fornell, C. Why do customer relationship management applications affect customer satisfaction? Journal of Marketing, 69, 4 (2005), 201-209.

49. Palmer, J. Web site usability, design, and performance metrics. Information Systems Research, 13, 2 (2002), 151-167.

50. Prahalad, C.K., and Krishnan, M.S. The new meaning of quality in the information age. Harvard Business Review, 77, 5 (1999), 109-118.

51. Prahalad, C.K.; Krishnan, M.S.; and Mithas, S. Customer relationships: The technology customer disconnect. Optimize (December 2002), 63-70 (available at www.optimizemag.com/ issue/014/customer.htm).

52. Raudenbush, S.W., and Bryk, A.S. A hierarchical model for studying school effects. Sociology of Education, 59, 1 (1986), 1-17.

53. Raudenbush, S.W., and Bryk, A.S. Hierarchical Linear Models: Applications and Data Analysis Methods, 2d ed. Thousand Oaks, CA: Sage, 2002.

54. Raudenbush, S.W.; Bryk, A.S.; Cheong, Y.F.; and Congdon, R.T. HLM5: Hierarchical Linear and Nonlinear Modeling. Chicago: Scientific Software International, 2000.

55. Ray, G.; Muhanna, W.A.; and Barney, J.B. Information technology and the performance of the customer service process: A resource-based analysis. MIS Quarterly, 29, 4 (2005), $625-652$.

56. Reichheld, F.F. The one number you need to grow. Harvard Business Review, 81, 12 (2003), 46-54.

57. Ring, P.S., and Perry, J.L. Strategic management in public and private organizations: Implications of distinctive contexts and constraints. Academy of Management Review, 10, 2 (1985), 276-286.

58. Rogers, E.M. Diffusion of Innovations. New York: Free Press, 1995.

59. Rust, R.T.; Moorman, C.; and Dickson, P.R. Getting return on quality: Revenue expansion, cost reduction, or both? Journal of Marketing, 66, 4 (2002), 7-24.

60. Rust, R.T.; Zeithaml, V.A.; and Lemon, K.N. Driving Customer Equity: How Customer Lifetime Value is Reshaping Corporate Strategy. New York: Free Press, 2000.

61. Saeed, K.A.; Grover, V.; and Hwang, Y. The relationship of e-commerce competence to customer value and firm performance: An empirical investigation. Journal of Management Information Systems, 22, 1 (Summer 2005), 223-256.

62. Srinivasan, R., and Moorman, C. Strategic firm commitments and rewards to customer relationship management in online retailing. Journal of Marketing, 69, 4 (October 2005), 193-200.

63. Straub, D.; Hoffman, D.; Weber, B.; and Steinfeld, C. Measuring e-commerce in Netenabled organizations: An introduction to the special issue. Information Systems Research, 13, 2 (2002), 115-124.

64. Zhang, P., and von Dran, G.M. Expectations and rankings of Website quality features: Results of two studies on user perceptions. In R.H. Sprague Jr. (ed.), Proceedings of the ThirtyFourth Hawaii International Conference on System Sciences. Los Alamitos, CA: IEEE Computer Society Press, 2001 (available at csdl2.computer.org/persagen/DLPublication.jsp?pubtype $=\mathrm{p} \&$ acronym $=$ hicss $)$.

65. Zhang, P.; von Dran, G.M.; Small, R.V.; and Barcellos, S. Websites that satisfy users: A theoretical framework for Web user interface design and evaluation. In Ralph H. Sprague Jr. (ed.), Proceedings of the Thirty-Second Annual Hawaii International Conference on System Sciences. Los Alamitos, CA: IEEE Computer Society Press, 1999 (available at csdl2.computer .org/persagen/DLPublication.jsp?pubtype $=\mathrm{p} \&$ acronym $=$ hicss $)$. 
Copyright of Journal of Management Information Systems is the property of M.E. Sharpe Inc. and its content may not be copied or emailed to multiple sites or posted to a listserv without the copyright holder's express written permission. However, users may print, download, or email articles for individual use. 